\title{
IMPEDING FACTORS FACED BY THE ENGLISH TEACHERS IN IMPLEMENTING TECHNOLOGICAL PEDAGOGICAL CONTENT KNOWLEDGE FRAMEWORK IN TEACHING AT SENIOR HIGH SCHOOLS IN BULELENG SUB-DISTRICT
}

\author{
N.W. Widyanti ${ }^{1}$, M.H. Santosa ${ }^{2}$, I.G.A.L.P. Utami ${ }^{3}$ \\ Jurusan Pendidikan Bahasa Inggris, Universitas Pendidikan Ganesha, Singaraja \\ e-mail : nw.widyanti@gmail.com, mhsantosa@undiksha.ac.id, lokitapurnamika@undiksha.ac.id
}

\begin{abstract}
Abstrak
Penelitian ini merupakan penelitian metode kualitatif yang memfokuskan dalam menginvestigasi faktor-faktor penghambat yang dihadapi oleh guru Bahasa Inggris dalam menerapkan kerangka TPACK dalam pembelajaran. Penelitian ini menggunakan wawancara dalam pengambilan data dengan berbantuan pada alat perekam suara (Handphone). Wawancara dilaksanakan untuk mengetahui faktor-faktor penghambat yang dihadapi oleh guru-guru dalam menerapkan kerangka TPACK dengan mengambil 9 guru Bahasa Inggris di seluruh sekolah menengah atas di kecamatan Buleleng. Hasil dari data interview yang diperolehakan diproses dengan menggunakan empat tahap analisis dari Miles and Huberman (1994) yaitu pengumpulan data, mereduksi data, menampilkan data dan simpulan atau verifikasi. Hasil dari penelitian ini menunjukan bahwa ada dua faktor yang menjadi penghambat dalam mengimplementasikan kerangka TPACK dalam proses belajar mengajar, yaitu fasilitas dan tingkah laku siswa. Namun hal ini dapat diatasi oleh setiap guru menggunakan fasilitas secara bergantian serta membuat peraturan untuk para siswa dalam penggunaan teknologi di dalam pembelajaran yang nantinya dapat memudahkan para guru.
\end{abstract}

Kata Kunci: Faktor Penghambat, Guru Bahasa Inggris, TPACK

\section{Abstract}

This study was qualitative research design focused on investigating the impeding factors faced by the English teachers in implementing technological pedagogical content knowledge framework in teaching. This study was investigated the interview using voice recorder (handphone) and took 9 English teachers in order to investigate the impeding factors faced by the teachers in implementing technological pedagogical content knowledge framework. The result of the interview data processed by using four analysis from Miles and Huberman (1994), namely data collection, data reduction, data display and conclusion drawing/verification. The result showed that there were two impeding factors faced by the English teachers at senior high schools in Buleleng sub-district in implementing technological pedagogical content knowledge framework in teaching, they were facilities and students' attitude. However, those could be solved by the teachers through does not using the facilities together in the same time and make the regulation for the students when implementing technology.

Keywords: English Teachers, Impeding Factors, TPACK

\section{Introduction}

Nowadays, people always keep in touch with technology in their environment. It shows by the use of gadget commonly in young children and adult' everyday life. They use their gadget for playing games. It makes them enjoy and happy. It means that the use of technology makes them fun and attract students' interest. That is why the educators need to use this condition as a way to make the students fun in learning by using technology. The educators need to follow this development because it can help them to attract students' motivation in learning by creating a new variation using technology, using what they like to be 
studied. That should be paid attention by the educators so the development of technology can give benefit in education (Koehler, Mishra, \& Cain, 2013).

Since all things already put in online (Santosa, 2017). It means that it a must for the educators to know and operate technology. In the same line, senior teachers that are not common in using technology, need to learn more about it. In addition, since the curriculum 2013 permanently establish in all schools in Indonesia, especially in Bali, the government already conducted a workshop to schools about how to integrating technology in the instructional process. The educators were invited to learn more in the workshop and are expected to implement it in the real teaching.

The combination of technology, content and also pedagogy in the instructional process is called TPACK. The effective teaching will be created by combining three main knowledge such as technology, pedagogy, and content (Mishra \& Koehler, 2006) of TPACK. The other combinationare PCK (Pedagogical Content Knowledge), TPK (Technological Pedagogical Knowledge), TCK (Technological Content Knowledge) and TPACK (Technological Pedagogical Content Knowledge) (Koehler \& Mishra, 2009).

Since TPACK is new in Indonesia (Mishra, Koehler, \& Bragg, 2006), that is way, TPACK is categorized as new in Indonesia especially in Buleleng, Bali. That is way the euphoria of TPACK can be a very good topic to be investigated. However, there is no study which investigate about the impeding factors faced by teachers in implementing technology in instructional process. In addition, the subject of this study was 9 English teachers at senior high schools in Buleleng sub-district. Which had an aim to investigate impeding factors faced by teachers in using technological pedagogical content knowledge (TPACK) in teaching English at senior high school in Buleleng sub-district.

\section{Research Method}

The design of this study was qualitative research design. The aim of this study was to investigate deeper data qualitatively (Creswell, 2014) regarding to the English teacher's impeding factors in implementing TPACK framework at senior high schools in Buleleng subdistrict. The subject of this study was English teachers around Buleleng sub-district. There were some reasons in choosing the subject of the study. First, English teachers was chosen because it was relevant with the researcher's major. Second, senior high schools were chosen because there is no study conducting related to the topic. Last, Buleleng sub-district was chosen because of limitation of the time. This study was conducted at Senior High Schools in Buleleng sub-district, especially for English teacher. There were 12 senior high schools in Buleleng sub-district. Moreover, after asking for permission, there were 8 schools that gave permission to use that schools as the target of the study. They were SMAN 1 Singaraja, SMAN 2 Singaraja, SMAN 3 Singaraja, SMAN 4 Singaraja, SMA Lab Undiksha, SMA Saraswati Singaraja, SMA Karya Wisata and SMA Bhaktiyasa Singaraja. Then each school gave only one representative. The questions for interview was developed from the part of TPACK through interview guide.

The data of this study were analyzed through qualitative analysis. In quantitative analysis was used theory from Miles and Huberman (1994). There are four interactive activities according to Miles and Huberman (1994), namely data collection, data reduction, data display and conclusion drawing/verification.

\section{Finding and Discussion}

Regarding to impeding factors faced by the teacher in implementing technological pedagogical content knowledge framework at senior high schools in Buleleng sub-district. The result was found that teachers' impeding factors in implementing technological pedagogical content knowledge become the main problem in technology implementation. There were two factors found, those were facilitation and students' attitude. The facilities included LCD and WiFi, while students' attitude refers to the habit and rules. 
First finding was facilities which included LCD and Wi-Fi. Based on the finding, there were 4 teachers who mentioned LCD as the impeding factor and there were 3 teachers who mentioned $\mathrm{Wi}-\mathrm{Fi}$ as the impeding factor.

"The impeding factor if there are crushing of the facilities such as on LCD and speaker. Sometimes, we (teachers) are going to use it but the LCD goes wrong and cannot be used. The same as the speaker, it will be difficult if there is listening section because the speakers are limited. Sometimes, it cannot be used together with other classes. In addition, there is a computer lab in this school but cannot be used together." (T3;F)

A similar review was stated by $\mathrm{T} 4$ and $\mathrm{T} 6$ :

"If we focus on e-learning which focus on the tools, our impeding factor was LCD, because there are some LCDs were broken." (T4;M)

"If supporting factor is good for example schools' facilities. There were LCDs but the number of LCD was limited" (T6;F)

In the same line stated with T9, T2, T7 and T8:

"If we see the impeding factor from facilities, it is not complete yet. There are some LCDs but it is limited. It is because in our schools there is construction. So, if it is done, the schools will add some LCDs and some facilities needed to implement technology in learning and teaching process." (T9;F)

"Sometimes we use technology so the WiFi was used by all students and teachers in this schools. It makes trouble. It makes our schools should increase the speed of the WiFi" (T2;F)

"Of course, because the use of media in learning for example the use of HP and internet connection make some trouble. The first one, we lack of internet connection (WiFi) because the speed of the WiFi needed to be increase. It disturbs teaching and learning process using technology." (T7;M)

"The impeding factor in our school was a lot. It is because the speed of WiFi needed to be increased and the students here are not ready in using technology." (T8;F)

Based on the result of the interview, there were 4 teachers who stated that LCD was one of the impeding factors in implementing technological pedagogical content knowledge while 3 teachers stated that WiFi was the impeding factors. The finding was also supported by the study from (Inan \& Lowther, 2010) stated that the use of technology in schools varies, it could be divided into three groups, they are technology for instructional preparation, technology for instructional delivery, and technology as a learning tool.

In addition, the use of LCD was belonged to technology for instructional delivery which was really important to be used in delivering material while WiFi was belong to technology as learning tool which was used to support the use of technology (Harris \& Hofer, 2011). It needed to be there in schools to help teaching and learning process run effectively. Even, there were 2 teachers (T1 and T2) who stated that the facilities such as LCD and WiFi were complete.

“The schools' facilities were complete, for example language lab, WiFi, LCD, speaker and the students are allowed to bring their gadget to school. So if we see from the facilities, there is no obstacle in it." $(\mathrm{T} 1 ; \mathrm{M})$

"The LCD and other tools needed already put in every classes. So, we are not really matter with the facilities. However, there is only problems with the speed of WiFi." $(\mathrm{T} 2 ; \mathrm{F})$ 
Even, there were 2 teachers stated that LCD and WiFi were not one of their impeding factors, still, the teachers who stated LCD and WiFi were the impeding factors in using technology more than 2 teachers. It was 5 teachers. So, it could not be used to rebut it.

In addition, two teachers stated that the impeding factor in implementing technology in instructional process was students' attitude. It was stated by T1 and T5.

"In my opinion, the impeding factor in implementing technology is controlling the students' attitude. It is so difficult to remind them in using technology in term of Hand Phone" (T1;M)

As the same with T5 who stated:

"The impeding factor in term of building the students' character in implementing technology, thinking positively and work hard. So, the student will be a person who has character and open minded." (T5;F)

From the discussion, it could be concluded that there were 10 dimensions in the questionnaire, they were technology, people, instructions, institution, technological knowledge, content knowledge, pedagogical content knowledge, technological content knowledge, technological pedagogical knowledge, and technological pedagogical content knowledge. The result showed that the English teachers in Buleleng sub-district are ready in implementing technological pedagogical content knowledge in teaching English but need few improvements. Those include, facilities (LCD and WiFi) and students' attitude. Based on the finding interview section, there are two major impending factors faced by the English teachers in Buleleng sub-district. It was facilities and students' attitude. Those may influence implementing of TPACK in teaching English.

\section{Conclusion}

Based on the finding above, regarding to teachers' impeding factors in implementing technological pedagogical content knowledge framework in teching English at Senior High Schools in Buleleng cub-district showed that there were two major impeding factors faced by the English teachers in implementing technological pedagogical content knowledge framework in teaching English at Senior High Schools in Buleleng sub-district, namely facilities and students' attitude. The facilities involved LCD and Wi-Fi. While students' attitude involved student attitude in implementing technology while learning. It means that the facilities and also rule for students in implementing technology in instructional process run well. It also stated by the interviewees which stated that they tried to solve those problem by not using the facilities together in the same time and creating the rule for students when the teachers used technology in teaching.

\section{References}

Creswell, J. W. (2014). Research design: Qualitative, quantitative, and mixed method. Research design qualitative quantitative and mixed methods approaches. https://doi.org/10.1007/s13398-014-0173-7.2

Harris, J. B., \& Hofer, M. J. (2011). Technological pedagogical content knowledge (TPACK) in action: A descriptive study of secondary teachers' curriculum-based, technologyrelated Instructional planning. Journal of Research on Technology in Education, 43(3), 211-229. https://doi.org/10.1080/15391523.2011.10782570

Inan, F. A., \& Lowther, D. L. (2010). Factors affecting technology integration in K-12 classrooms: A path model. Educational Technology Research and Development, 58(2), 137-154. https://doi.org/10.1007/s11423-009-9132-y 
Koehler, M. J., \& Mishra, P. (2009). What is Technological Pedagogical Content Knowledge (TPACK)? Contemporary Issues in Technology and Teacher Education, 9(1), 60-70. https://doi.org/10.1016/j.compedu.2010.07.009

Koehler, M. J., Mishra, P., \& Cain, W. (2013). What is Technological Pedagogical Content Knowledge (TPACK)? Journal of Education, 193(3), 13-19. https://doi.org/10.1016/j.compedu.2010.07.009

Miles, M., \& Huberman, A. (1994). Designing matrix and network displays. Qualitative Data Analysis A Methods Sourcebook, 107-119. https://doi.org/10.1136/ebnurs.2011.100352

Mishra, P., Koehler, M. J., \& Bragg, W. H. (2006). Technological Pedagogical Content Knowledge: A framework for teacher knowledge the advent of digital technology has dramatically changed routines and practices in most arenas of human work. Advocates of technology in ed- ucation often envisage similar dra. Teachers College Record, 108(6), 1017-1054. https://doi.org/10.1111/j.1467-9620.2006.00684.x

Mishra \&Koehler. (2006). The Technological Pedagogical Content Knowledge Framework for teachers and teacher educators. ICT iltegrated Teacher Education: A Resource Book, $2-7$.

Santosa, M. H. (2017). Learning approaches of Indonesian EFL Gen Z students in a Flipped Learning context. Journal on English as a Foreign Language, 7(2), 183.

https://doi.org/10.23971/jefl.v7i2.689 